\title{
PELATIHAN DAN PENGEMBANGAN ENTREPRENEUR KREATIF PADA PENGELOLA KOPERASI DI SMP NEGERI 25 KERINCI
}

\author{
Mohamad Muspawi, Sophia Rahmawati, Bradley Setiyadi* \\ FKIP Universitas Jambi \\ *bradleysetiyadi@unja.ac.id
}

\begin{abstract}
"Koperasi" is an association consisting of individuals or legal entities to run a joint business by working together in a family manner to achieve the welfare of its members. The position of "koperasi" in the Indonesian economy is stated in article 33 of the 1945 Constitution which places "koperasi" as one of the economic sectors in their position as: (a). The pillar of the national economy teacher. (b). An integral part of the national economic system. (c). The role of "koperasi"s in the economic life of the Indonesian nation. The purpose of this coaching and training workshop is expected to be able to foster an entrepreneurial spirit, practical management knowledge, as well as knowledge and skills to manage "koperasi", so as to be able to develop entrepreneurship for "koperasi" Managers at SMP Negeri 25 Kerinci located in Desa Pelompek, Kecamatan Gunung Tujuh, Kabupaten Kerinci. The methods that will be used in this integrative community service program are through: a) the lecture method; b) theoretical integrative method, practical experience and practice or demonstration practice (based on the material); c) as well as tutorials through practical management approaches (production management, financial management, marketing management, etc.), small-micro business management and entrepreneurship (by substance).
\end{abstract}

Keywords: coaching; training; entrepreneurship; "koperasi"

\begin{abstract}
Abstrak
Koperasi adalah suatu perkumpulan yang beranggotakan orang-orang atau badan hukum untuk menjalankan usaha bersama dengan cara bekerja sama secara kekeluargaan untuk mencapai kesejahteraan para anggotanya. Kedudukan Koperasi dalam perekonomian Indonesia tercantum pada pasal 33 Undang-Undang Dasar 1945 yang menempatkan koperasi sebagai salah satu sektor ekonomi dalam kedudukannya sebagai: (a). Soko guru perekonomian nasional. (b). Bagian integral tata perekonomian nasional. (c). Peranan koperasi dalam kehidupan ekonomi bangsa Indonesia. Tujuan dilaksanakannya workshop pembinaan dan pelatihan ini diharapkan mampu menumbuhkan jiwa kewirausahaan, pengetahuan manajemen praktis, serta pengetahuan dan keterampilan mengelola koperasi, sehingga mampu mengembangkan kewirausahaan bagi Pengelola Koperasi di SMP Negeri 25 Kerinci yang terletak di Desa Pelompek, Kecamatan Gunung Tujuh, Kabupaten Kerinci. Metode yang akan digunakan dalam program pengabdian mayarakat Integratif ini adalah melalui: a) metode ceramah; b) metode integratif teoritis, pengalaman praktis dan praktek atau praktek demonstrasi (berdasarkan materinya); c) serta tutorial melalui pendekatan manajemen praktis (manajemen produksi, manajemen keuangan manajemen pemasaran, dsb), manajemen usaha kecil-mikro dan kewirausahaan (berdasarkan substansinya).
\end{abstract}

Kata Kunci: pembinaan; pelatihan; kewirausahaan; koperasi

\begin{tabular}{l|l|l} 
Submitted: $2021-09-29$ & Revised: $2021-10-18$ & Accepted: 2021-10-26
\end{tabular}

\section{Pendahuluan}

Kedudukan Koperasi dalam perekonoimian Indonesia tercantum pada pasal 33 UUD 1945 . Menempatkan koperasi sebagai salah satu sektor ekonomi dalam kedudukannya sebagai: (a). Soko guru perekonomian nasional. (b). Bagian integral tata perekonomian nasional. (c). Peranan koperasi dalam kehidupan ekonomi bangsa Indonesia. Oleh karena itu, pengembangan bagi pengelola koperasi untuk berwirausaha selayaknya harus terus diupayakan agar peran pentingnya dalam perekonomian bangsa tetap terjaga. Namun, permasalahan bangsa yang kompleks saat ini berdampak buruk bagi pengembangan sektor wirausaha yang cenderung berjalan lambat. Berwirausaha merupakan satu alternatif jalan keluar terbaik. Wirausaha adalah orang yang memiliki dan mengelola serta menjalankan usahanya. Wirausaha didefinisikan sebagai orang yang memiliki gagasan (idea man) dan manusia kerja (man of action) sering dikaitkan orang yang inovatif atau kreatif (Isenberg, 2008). Orang yang mendorong perubahan sangat penting dalam menemukan kemungkinan-kemungkinan baru. Wirausaha adalah orang yang suka mengambil resiko dan mampu mengembangkan kreatifitasnya. 
Pengabdian ini dilakukan dalam upaya peningkatan pengetahuan, keterampilan mengenai manajemen keuangan dan pengelolaan koperasi dalam upaya menumbuhkan jiwa berwirausaha, untuk membantu berkontribusi secara nyata bagi peningkatan pendapatan ekonomi koperasi. Dengan melihat fenomena - fenomena yang diungkapkan tersebut, maka menjadi sebuah kepentingan untuk melakukan pelatihan/pembinaan kepada para pengelola koperasi sebagai Pengurus Koperasi. Sementara tujuan pengabdian ini adalah untuk menumbuhkan jiwa kewirausahaan, pengetahuan manajemen praktis, serta pengetahuan dan keterampilan mengelola koperasi, sehingga mampu mengembangkan kewirausahaan bagi pengelola koperasi:

1. Bagaimana mindset dan pemahaman pengelola koperasi dalam memanfaatkan situasi, konsidi serta potensi yang ada dalam lembaganya menjadi sebuah peluang untuk mengembangkan inovasi usaha?

2. Bagaimana membekali pengetahuan mengenai wirausaha bagi pengelola koperasi dilihat dari kerangka teoretis dan ilmu pengetahuan?

3. Bagaimana membekali keterampilan wirausaha kepada pengelola koperasi sebagai upaya menciptakan pengelola koperasi yang terampil, mandiri dan berjiwa kewirausahaan?

4. Bagaimana implikasi pelatihan wirausaha bagi pengelola koperasi untuk menjadi terampil dan mandiri?

Workshop pembinaan dan pelatihan ini diharapkan mampu menumbuhkan jiwa kewirausahaan, pengetahuan manajemen praktis, serta pengetahuan dan keterampilan mengelola koperasi, sehingga mampu mengembangkan kewirausahaan bagi Pengelola Koperasi di SMP Negeri 25 Kerinci.

\section{Metode}

Metode yang digunakan dalam pelaksanaan program pelatihan wirausaha ini adalah metode kaji tindak partisipatif karena program pelatihan ini dilakukan sebagai upaya meningkatkan kemampuan pengelola koperasi di SMP Negeri Pelompek Kabupaten Kerinci. Dengan menggunakan metode kaji tindak partisipatif diharapkan dapat menciptakan keyakinan bahwa pengelola koperasi mampu untuk memperbaiki kehidupan dengan kekuatan sendiri dengan menganalisa potensi yang ada di lingkungan masyarakat. Metode yang akan digunakan dalam program pengabdian mayarakat Integratif ini adalah melalui: a) metode ceramah; b) metode integratif teoritis, pengalaman praktis dan praktek atau praktek demonstrasi (berdasarkan materinya); c) serta tutorial melalui pendekatan manajemen praktis (manajemen produksi, manajemen keuangan manajemen pemasaran, dsb), manajemen usaha kecil-mikro dan kewirausahaan (berdasarkan substansinya).

Tabel 1. Materi Pelatihan

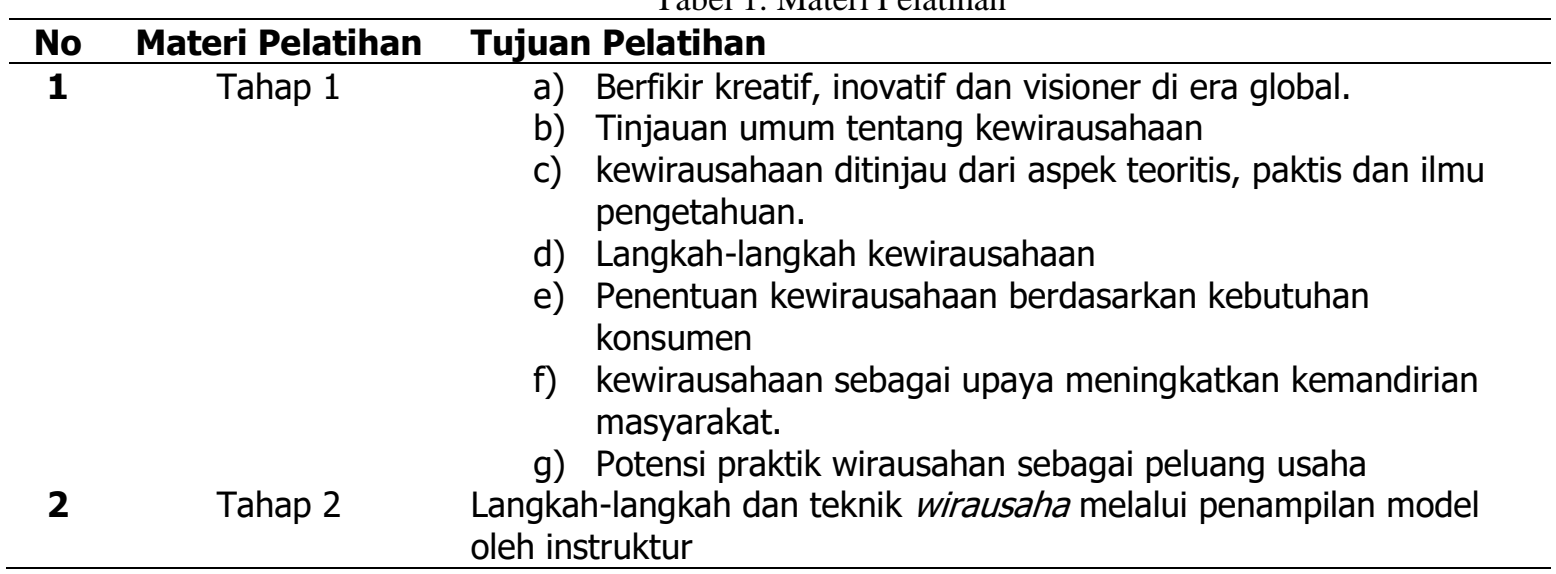




\begin{tabular}{ccl}
\hline No & Materi Pelatihan & Tujuan Pelatihan \\
\hline $\mathbf{3}$ & Tahap 3 & Praktik wirausaha oleh peserta terhadap peserta lain secara \\
& & bergiliran \\
$\mathbf{4}$ & Tahap 4 & Diskusi dan evaluasi \\
$\mathbf{5}$ & Tahap 5 & Penentuan rencana tindak lanjut \\
\hline
\end{tabular}

\section{Hasil dan Pembahasan}

Sebagai wujud pengabdian pada masyarakat Universitas Jambi merupakan lembaga yang sangat kompeten dalam program pengabdian masyarakat berupa pembinaan dan pelatihan dalam mengembangkan jiwa wirausaha yang kreatif dan mandiri bagi Pengelola Koperasi di SMP Negeri Pelompek Kabupaten Kerinci. Dengan kegiatan ini diharapkan dapat meningkatkan pemahaman tentang berwirausaha. Adapun rincian pelaksanaan kegiatan pengabdian ini, yaitu :

Tabel 2. Materi Pendampingan

\section{No. Materi Pendampingan}

\begin{tabular}{ll}
\hline 1 & Sosialisasi dan pendaftaran \\
a. Materi wirausaha dan change mindset enterpreneurship \\
b. Strategi dan manajemen usaha
\end{tabular}

Kegiatan pengabdian ini memberikan pembinaan dan pelatihan dalam mengembangkan jiwa wirausaha yang kreatif dan mandiri bagi Pengelola Koperasi di SMP Negeri Pelompek Kabupaten Kerinci sehingga kegiatan ini mampu menciptakan dan meningkatkan pemahaman tentang berwirausaha. Jiwa Enterpreunership yaitu proses kemanusiaan (human process) yang berkaitan dengan kreativitas serta inovasi dalam memahami peluang, mengorganisasi sumbersumber, mengelola sehingga peluang itu terwujud menjadi suatu usaha yang mampu menghasilkan laba atau nilai untuk jangka waktu yang lama. Definisi tersebut menitikberatkan kepada aspek kreativitas serta inovasi, karena dengan sifat kreativitas serta inovatip seseorang dapat menemukan peluang. Mampu meningkatkan Kreativitas untuk membuat kombinasikombinasi baru atau hubungan-hubungan baru antar unsur, data, variabel yang sudah ada sebelumnya. Dengan menggunakan metode kaji tindak partisipatif diharapkan dapat menciptakan keyakinan bahwa pengelola koperasi mampu untuk memperbaiki kehidupan dengan kekuatan sendiri dengan menganalisa potensi yang ada di lingkungan masyarakat.

Cara mengembangkan inovasi dalam etntrepreneurship dapat dilakukan dengan berbagai cara, yang pertama adalah wirausahawan tersebut harus mengenali hubungan. Banyak penemuan dan inovasi lahir sebagai cara pandang terhadap suatu hubungan baru dan berbeda antara objek, proses, bahan, teknologi dan orang. Untuk membantu kreatifitas, kita dapat melakukan cara pandang kita terhadap hubungan kita dengan lingkungan alam sekitar. Orang yang kreatif akan memiliki hubungan intuisi tertentu untuk dapat mengembangkan dan mengenali hubungan yang baru. Selain itu untuk dapat melakukan kreativitas agar dapat berimajinasi yang inovatif gunakanlah otak bagian kanan, sedangkan otak bagian kiri digunakan untuk bekerja. Proses kreativitas yang inovatif meliputi pemikiran logis dan analitis terhadap pengetahuan, evaluasi dan tahap implementasi. Jadi bila kita ingin lebih kreatif, kita harus melatih dan mengembangkan kemampuan kedua otak kita tersebut. Dan yang terakhir, untuk menjadi seorang yang kreatif dan 
inovatif dalam berwirausaha, maka kita harus selalu berfikir positif agar dapat menjadi orang yang sukses.

Permasalahan utama di masyarakat yang menjadi mitra kegiatan pengabdian ini adalah masyarakat produktif yang menghasilkan pelayanan berupa jasa. Namun terdapat kendala dalam pengelolaan koperasi di sekolah yang merupakan implementasi dari kegiatan kewirausahaan antara lain: (1) belum maksimalnya manajemen kewirausahaan dengan baik, (2) masih terbatasnya pengetahuan pengelola tentang inovasi produk/jasa yang ditawarkan, (3) terbatasnya memperoleh keterampilan pengelolaan koperasi sebagai kegiatan usaha. Disinilah peran melatih dan membina guna menumbuhkan kewirausahaan yang mandiri dan kreatif. Tujuan utama kegiatan ini adalah menumbuhkan jiwa wirausaha dengan harapan melalui kegiatan ini dapat dikembangkan pengelola sebagai pelaku bisnis/usaha di sekolah. Adapun sebagai rencana awal pelatihan dan pembinaan jiwa wirausaha ini maka peserta perlu memahami analisis lingkungan sebagai skema bisnis sebagai berikut:

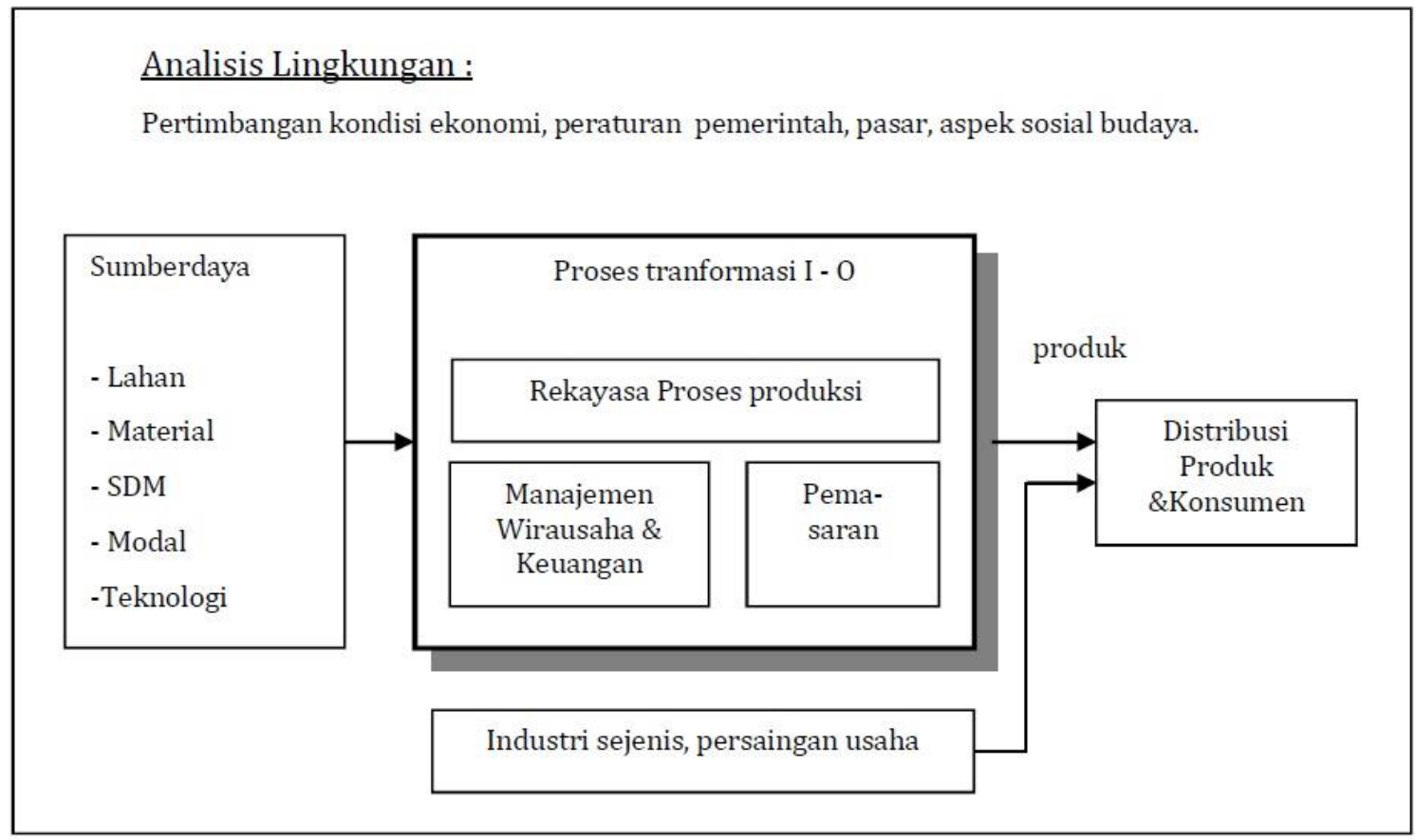

Gambar 1. Skema Bisnis dan Pengembangan Usaha

Ada dua aspek penting pada kreatifitas yaitu proses dan manusia. Proses yang berorentasi tujuan, yang di desain untuk mencapai solusi suatu permasalahan. Sedangkan manusia merupakan sumber daya yang menentukan solusi. Proses tetap sama, namun pendekatan yang digunakan dapat bervariasi. Antara wirausahawan yang satu dan yang lainnya pastilah melakukan cara atau strategi yang berbeda-beda dalam membangun bisnisnya. Cara atau strategi inilah yang menentukan hasil akhir yang dihasilkan. Semakin kreatif orang tersebut menggunakan peluang yang ada, maka semakin baik pula hasil dari bisnis yang mereka jalankan. Selain kreatif, hal lain yang diperlukan dalam berwirausaha adalah inovatif. Dengan inovasi, wirausahawan menciptakan baik sumber daya produksi baru maupun pengelolahan sumber daya yang ada dengan peningkatan nilai potensi untuk menciptakan sesuatu yang tidak ada menjadi ada. Pada saat pelatihan (workshop) peserta diajak berdiskusi dan berpartisipasi aktif dalam topik dunia wirausaha dan pengelolaan koperasi oleh pemateri. Selain itu penggunaan kata dan pola diskusi yang mampu diterima oleh pengelola dapat memberikan mereka semangat dan antusiasme dalam mengikuti 
kegiatan sampai akhir. Dalam kaitan dengan meningkatkan pengetahuan dan keterampilan dalam mengelola koperasi .

Koperasi di SMP Negeri 25 Kerinci sudah ada dan berjalan dengan baik. Hanya saja pengelolaannya yang belum maksimal. Kegiatan pengabdian ini memberikan pembinaan dan pelatihan dalam mengembangkan jiwa wirausaha yang kreatif dan mandiri bagi Pengelola Koperasi di SMP Negeri 25 Kerinci sehingga kegiatan ini mampu menciptakan dan meningkatkan pemahaman tentang berwirausaha. Jiwa Enterpreunership yaitu proses kemanusiaan (human process) yang berkaitan dengan kreativitas serta inovasi dalam memahami peluang, mengorganisasi sumber-sumber, mengelola sehingga peluang itu terwujud menjadi suatu usaha yang mampu menghasilkan laba atau nilai untuk jangka waktu yang lama. Definisi tersebut menitikberatkan kepada aspek kreativitas serta inovasi, karena dengan sifat kreativitas serta inovatip seseorang dapat menemukan peluang. Mampu meningkatkan Kreativitas untuk membuat kombinasi-kombinasi baru atau hubungan-hubungan baru antar unsur, data, variabel yang sudah ada sebelumnya.

\section{Kesimpulan}

Kegiatan ini memberikan dampak positif terhadap pengelola koperasi sekolah maka dari itu perlu dilakukan kesinambungannya dan tidak hanya saja pada pengelola koperasi sasaran namun melibatkan semua masyarakat sekolah dengan melakukan kegiatan dan melibatkan semua maka koperasi sekolah akan maju dan berkembang. Kerjasama antara pihak sekolah dan masyarakat tidak hanya memberikan manfaat bagi SMP Negeri 25 Kerinci, namun juga bagi masyarakayt di Desa Pelompek, Kecamatan Gunung Tujuh.

\section{Daftar Pustaka}

Isenberg, D. J. (2008). The global entrepreneur. Harvard Business Review, 86(12). https://doi.org/10.1016/j.jom.2003.12.007

Pardian, P., Utami, HN., dan Sadeli, AH. (2017). manajemen praktis usaha mikro berbasis agroindustri sebagai upaya menumbuhkan jiwa kewirausahaan petani sebagai pelaku agribisnis di desa palasari dan desa cisaat kec. ciater kab. Subang. Ethos (Jurnal Penelitian dan Pengabdian Masyarakat): 313-326 Vol 5, No.2, Juni 2017.

Sitio, Arifin dan Halomoan Tamba. (2001). Koperasi Teori dan Praktik.Jakarta:Penerbit Erlangga

Sukamdiyo, Ign. (1996). Manajemen Koperasi.Jakarta:Penerbit Erlangga

Muhtarom, Nizaruddin \& Zuhri. (2017). Pelatihan kewirausahaan di Universitas PGRI Semarang. EDimas Jurnal Pengabdian Pada Masyarakat. Vol 8 No. 1 (2017). 